\title{
Leadership in the civic arena
}

\author{
David Chrislip \\ Senior Fellow, Kansas Leadership Center, Wichita, KS, USA
}

\section{Jill Arensdorf}

Chair and Associate Professor, Department of Leadership Studies, Fort Hays State University, Hays, KS, USA

\section{Timothy Steffensmeier}

Associate Professor, Communication Studies, Kansas State University, Manhattan, KS, USA

\section{Mary Hale Tolar}

Director and Associate Professor, Staley School of Leadership Studies, Kansas State University, Manhattan, KS, USA

This paper focuses on leadership in the civic arena. Over the past four decades the field of leadership studies has moved away from a narrow leader-centric focus to a more expansive view that includes other dimensions such as the leader's relationship with followers and the fulfillment of the needs of both leaders and followers. But this progress within the field has not been matched by a similar shift in popular cultural conceptions of leadership. Our hypothesis is that the dominant cultural narrative of leadership with its central focus on the authority of the leader is inadequate for making progress in the civic arena. We need a more capacious and flexible conception of leadership to help address complex civic challenges. In this paper we explore the dominant cultural narrative of leadership and its communicative practices. We analyse the civic context to which leadership must respond. We discuss corrective experiments that attempt to make leadership more responsive to this context. We define the gap between how the dominant cultural narrative describes leadership and what's needed in this particular context. Finally, we ask the field to help reshape this dominant cultural narrative to reflect contemporary understandings of leadership within the field and to help advance the study of leadership in the civic context through research, pedagogy, and practice.

Keywords: leadership, civic leadership, dominant cultural narrative, civic context, adaptive challenges, diagnosis, affective energy

\section{INTRODUCTION}

For decades, the residents of seventeen counties in southeast Kansas have been amongst the poorest and least healthy in the state. Compounding this reality, a 2009 county-by-county study of health and its determinants implied that the overall health of the region's residents would continue to decline unless powerful interventions could move the trends in a positive direction (Kansas Health Institute 2009, pp. 7-14). Most residents were well aware of the region's history and the lack of progress in addressing persistent deficits in health, the economy, and local leadership. The inability of each 
county to move beyond a self-imposed isolation to find common cause with its neighbors worsened the situation. While the problems themselves were wicked enough, the real challenge facing the region would be to mobilize a critical mass of people to make a difference. After long years of collective inaction, in November 2011 more than 300 residents of these seventeen counties gathered at the Southeast Kansas Economic Summit to begin Project 17: Together We Succeed to address common challenges.

Project 17 got its start when four state senators concerned with the region's economy organized the Summit. The meeting marked the beginning of an intermediary organization that would use a 'network-based approach' to provide opportunities for the 'everyday citizen' to be heard (Project 17 Mission and Principles 2011). Initially funded by state and federal economic development grants, the initiative was designed 'to develop the alliances necessary to pull the region together' (McLean 2011). Speaking at the Summit, Kansas Governor Sam Brownback encouraged the group to 'get beyond politics and slogans with an eye toward workable solutions' (ibid.).

In this paper, we use Project 17 as a means to highlight the complexities of working in the civic arena and the leadership challenges it presents. Our hypothesis is that the dominant cultural narrative of leadership with its central focus on the authority of the leader is inadequate for making progress in this arena. This descriptive example exposes some of these shortcomings and helps define the gap between how the dominant cultural narrative describes leadership and what's needed in the civic context. We discuss corrective experiments that attempt to make leadership more responsive to this context and suggest new areas for experimentation. Finally, we ask the field to help shift this dominant cultural narrative to reflect contemporary understandings of leadership within the field and to help advance the study of leadership in the civic context through research, pedagogy, and practice.

\section{A limiting conception of leadership}

Most residents of this southeast Kansas region shared a common conception of leadership. If you held a position of authority or possessed relevant expertise you were seen as a leader. The vast majority of residents deferred to those with position or expertise, robbing the region of needed energy and allowing many to blame those in power for the failure to make progress while avoiding the responsibility for the work. If Project 17 was to succeed, this limiting conception of leadership would have to change. As in other contexts, old models of leadership were breaking down while new models were slow to emerge (Kellerman 2015, pp. 9-10; Sanders 2014, pp. 143-144).

One of the top priorities identified by participants in the Project 17 Summit was that many more people would have to be willing and able to serve in community leadership roles hand-in-hand with those with authority and expertise. During this time, the Kansas Leadership Center (KLC), a statewide organization focused on civic leadership development, offered a $\$ 1$ million grant for leadership training. Organizations doing civic work in the state would compete for the grant. A committee of community leaders from Project 17 applied for the grant as a strategy for developing leadership in southeast Kansas. KLC awarded the grant to Project 17, providing hundreds of people across the region an opportunity to engage in its leadership development programs.

These programs operate from the premise that a different kind of leadership is required to make progress on the adaptive challenges that Project 17 had identified. Leadership is not exclusive to those with authority or expertise. It is an intentional activity that can be learned. Anyone can exercise leadership at any time. Progress starts 
with the individual and must engage others. Leadership development remains one of the central priorities of Project 17 through its continued involvement with KLC trainings, local community leadership programs, and youth development initiatives.

\section{No one in charge}

On the Project 17 website, a collage of photos of the four state senators who had launched the initiative implied that these authority figures were in charge of the work. Within one election cycle, two of those senators were no longer in office. Without elected officials as the face of Project 17 and with multiple jurisdictions across the region, who had the authority to do this work? Was there any structure that could bring people together when most citizens did not see themselves as part of a region?

Situations like this tempt most people to impose a top-down decision-making structure with an authority figure to guide the work. Project 17 was no exception. For example, after receiving the leadership development grant it was unclear who was responsible for getting people to participate in the leadership development training. At this point, an executive director was hired with the expectation that she would get things done. This desire for direction and results created a tension with the equally important desire to hear from people across the region allowing them to shape the group's agenda and actions. The limitations of top-down approaches to complex, multi-jurisdictional issues were coming to the fore just as they had in many other settings (The Economist 2013, p. 70; Lasker and Weiss 2003, pp. 18-21; Peirce and Johnson 1997, table of contents; Sanders 2014, p. 138).

\section{Lack of commitment and energy}

Project 17's challenges demand a long-term commitment and a substantial investment of energy on the part of its residents. That is a difficult proposition when there is little history of collaboration. For the better part of the last century a scarcity of resources and economic opportunity has been the norm in the region. Wins in community development were achieved by out-competing neighboring towns. How do you create a shared purpose when 'your little town' is not at the center of the conversation (McLean 2011)? How could anyone energize the region's residents to address these challenges in a collaborative way?

The work of Project 17 has focused primarily on economic development with different initiatives and projects specific to particular municipalities or counties. More recently, a mutual commitment to address poverty by employing a national model promoted by Circles USA has emerged. Many Project 17 communities have launched local 'Circles' initiatives and are sharing best practices and learnings with their regional neighbors as a means of building a sense of shared concern and identity.

\section{Ambiguity about how to measure progress}

The state and federal grants used to initiate Project 17 raised expectations that progress would be measurable and timely. The group was under immense pressure to get concrete things done that would demonstrate that this money was well spent. Governor Brownback said that the new initiative should be regularly subjected to 'the cruelty of the data check' using solid indicators of improvement (McLean 2011). Charles Fluharty, president of the Rural Policy Research Institute and one of the speakers at 
the Summit, noted, on the other hand, that 'it would take years before it would become clear whether the initiative succeeded' (ibid.).

These two comments imply different approaches to measuring progress and to the process of engagement. The pressure for quick results tracked via 'solid indicators' and regular 'data checks' to please funders and sponsors often pre-empts a deeper diagnosis of the challenges and limits the future flexibility of the process. Groups like Project 17 haven't yet developed enough trust and shared understanding to do this work well early on. The idea that progress might take years, in contrast, recognizes the ambiguous and adaptive nature of the challenges and the need for learning and experimentation stakeholders discovering the way as they go - to respond effectively. In this case, comparative measures of success - are or will we be better off? - allow the group to move ahead without forcing agreement on indicators and a vision before they are ready. What measures of progress would give Project 17's supporters and the people in the region the confidence that they were moving ahead in expedient and productive ways?

It's not yet clear whether Project 17's initiatives, including the leadership development effort, will yield significant results. What is evident is that it is an exemplar of one region's attempt to grapple with seemingly unyielding civic challenges in new and different ways.

Beyond the Project 17 example, other analysts have called attention to the complexities of the civic context. In 1997, civic journalists Neal Peirce and Curtis Johnson examined the challenges facing several American cities in their monograph, Boundary Crossers: Community Leadership Comes of Age (1997). Their descriptions of these challenges approximate those of Project 17: the table gets larger and rounder (p. 10); the agenda gets tougher (p. 22); there is no magical leadership structure (p. 28); no one's excused (p. 34); and it's never over (p. 58). In its first year of operation, 2007, the Kansas Leadership Center conducted interviews and focus groups with several hundred Kansas residents to better understand the state's civic context and challenges. In this assessment, 'Kansans portrayed a singularly unimaginative and unproductive civic culture in which deference to authority and government, shirking of civic responsibility, widespread complacency and apathy have eroded historic norms of trust, tolerance, and reciprocity' (Chrislip and O'Malley 2013, p. 13). Roz Lasker and Elisa Weiss, in their public health work, described challenges that could not be solved by 'any person, organization, or sector working alone.' These problems defy easy answers, affect diverse populations in different local contexts, and are dependent on decisions made elsewhere (ibid., p. 15).

In his book Bowling Alone, political scientist Robert Putnam (2000) investigated a larger phenomenon, the decrease of social capital in America. He documented the precipitous decline since about 1970 of two measures of social capital - informal social connections and formal civic engagement - and noted the strong connections between these measures and the civic health of the community and nation. He was particularly concerned with the diminishment of 'bridging' social capital, the critical capacity of the public to constructively come together across dividing lines to discover the broader public interest (ibid., pp. 362-363). The deterioration of American civic life he observed further complicates making progress in the civic arena.

Faced with these obstacles, we wondered where to go for advice about what it takes to mobilize people across geographical, sectorial, and factional lines to make progress on daunting civic challenges where no formal authority exists? Leadership studies, steeped in the theories and practices of change, would seem a natural fit, yet a search for references to civic leadership or leadership in the civic arena yields little return. While the vast literature on leadership provides a wealth of knowledge about the leader 
and how he or she interacts with his or her followers (Baker 2007, p. 57; Dinh et al. 2014, pp. 38-39; Graen and Uhl-Bien 1995, p. 225), it offers little about what it takes to initiate and facilitate collective action with scant or no authority.

Leadership scholar Richard Couto draws a similar conclusion. He notes that the idea of civic leadership "challenges the conceptual boundaries that we set for leadership and politics' (Couto 2014, p. 347). He questions the viability of traditional leader-centric conceptions in an arena where power and authority are limited. He concludes that a different leadership lexicon and practice is paramount to progress in the civic arena.

The civic arena is distinct from traditional descriptions of the political sphere because it must take on issues that go beyond the jurisdictional boundaries of government or because those in political positions either fail to or cannot provide effective leadership on challenges of common concern (Chrislip and O'Malley 2013, pp. 19-20). Couto (2014, p. 352) puts it this way: 'The space of civil society, which defines civic leadership, requires some degree of autonomy from government and economic actors ... and brings people together individually and in associations ... to envision and practice democratic forms of increased equality, representation, and participation in decision making on public matters.' When government and the market can't or don't get it right, a strong civil society and leadership from anyone who cares enough to help address common concerns compensate for these imperfections.

\section{THE DOMINANT CULTURAL NARRATIVE OF LEADERSHIP}

The evidence of a dominant cultural narrative of leadership is stupefying. The Economist magazine likens the typical corporate chief executive to a silverback male gorilla: tall, fit, graying, and ruggedly handsome with a deep resonant voice. The magazine goes on to report that a talk by Amy Cuddy of Harvard Business School on 'power poses' is now the second-most downloaded TED talk (The Economist 2014 , p. 68). Students entering a university leadership program overwhelmingly see leaders as sole actors influencing followers or as exemplars for their peers (Kosempel and Olson 2013). The three most popular images of leadership in a survey conducted by the Center for Creative Leadership were those of a warrior, a music conductor, and shaking hands (leading by example and using the talents of different team members effectively) (Gentry et al. 2014, p. 3). As the 2016 US presidential campaigns indicate, when societies feel threatened they tend to turn to candidates they perceive as powerful and decisive. The strong leader is a 'good thing' (Brown 2014, p. 1). Myths feed cultural conceptions of leadership. This leader-centric focus offers little help in the chaotic realm of civic action.

The fields of leadership studies and communication studies help inform our understanding of this dominant cultural narrative. ${ }^{1}$ Leadership is experienced through communicative practices and the two fields have followed parallel and complementary paths throughout much of the last century. Both have focused on a person (the speaker, the leader) engaging others (the audience, the followers) to move them to agreement and action. Four common themes characterize the dominant cultural story of leadership and rhetoric: leadership derives from a position of authority or influence (the speaker); the leader must perform (the orator); the successful leader wins in the competition of

1. The communication studies field has been informed by multiple academic traditions including rhetoric. The rhetorical tradition, commonly taught as public speaking and debate, has shaped the communicative practices we address in this paper. 
ideas and influence (the victor); and the hierarchical relationship between the leader and the follower (the audience).

\subsection{Leadership and authority}

Numerous biographies have been written about leaders with positional authority who have the capacity to command the deference of followers. Leadership is often defined by the rank or status of the person in a hierarchy. Leaders comprise an elite group whose members are commonly selected by others already acknowledged as leaders. Corporate selection committees, The Economist (2014, p. 68) observes, 'continue to look for the " $\mathrm{x}$ " factor and find, strangely enough, that it resides in people who look remarkably like themselves.' This conflation of leadership with authority and position defines the role of follower: 'followers are subordinates who have less power, authority, and influence than do their superiors, and who therefore usually, but not invariably, fall into line' (Kellerman 2012, p. xx). This relationship between leader and follower is described as a social contract 'in which the leader, whether despot or democrat, is generally expected to control the action, while followers are generally expected to go along' (ibid., p. 69). In the rhetorical model, a speaker chooses from the available means of persuasion to influence an audience. One of the primary ways to appeal to an audience is ethos, the credibility of the speaker (Aristotle 1991, p. 37).

\subsection{The leader as performer}

The dominant cultural narrative expects the leader - the person holding positional authority - to perform. Leaders must share a grand vision, mobilize others, prescribe actions, and, ultimately, deliver results (Burns 1978, p. 22). Key indicators such as influence and persuasion help gage a leader's effectiveness just as they do in the rhetorical tradition. The ability to speak persuasively is essential in a rigorous rhetorical education. In Aristotle's time, the curriculum started with storytelling at a young age and culminated with an exercise requiring graduates to defend and attack a current law (Crowley and Hawhee 1999, p. 362). Successful graduates had to gain the assent of the audience. Cicero (46 $\mathrm{BC}$ [1899], 21.1) describes the orator's task as: 'To prove, is necessary for him; to delight, is a proof of his sweetness; to persuade, is a token of victory. For that alone of all results is of the greatest weight towards gaining causes.' In this view, an eloquent performance that influences others is the highest purpose of human language. Similarly, 'gaining causes' through persuasion is a measure of effective leadership.

Not much has changed since the Greek city-states were establishing communicative processes to nourish democratic governance. Political communication today is dominated by leaders putting forth eloquent rhetorical performances. In the mold of Martin Luther King, Jr, the ideal orator addresses the crowd from a position of influence. Though few can match King's charismatic performances, the expectation that a leader must perform eloquently while addressing the greatest challenges of the day remains (Cronin and Genovese 2012, p. 310).

\subsection{The leader as victor}

The positional and performance aspects of the dominant cultural narrative of leadership match the competitive context in which they occur. We understand that effective 
leadership takes place in an arena of conflict and competition (Burns 1978, p. 36; Cronin and Genovese 2012, p. 56). We expect leaders to have an agenda and move it forward. Competing for an audience's consent is a central tenet of democratic legal systems. A competitive public sphere fosters a clash of ideas among adversaries where the best ideas are adopted and the lesser ones discarded. Hannah Arendt (1998), concerned with protecting human particularity as a counter-force to totalitarian regimes, contends that an agonistic public sphere where individuals freely debate with one another is central to democracy. This agonistic approach also undergirds a central assumption in capitalist economic theory: many actors enter the marketplace of ideas, and those that the audience responds to the most rise to the top. Similarly, a liberal defense of free speech has 'faith in the power of airing of ideas to reveal truth over the din of public relations and the dullness of public ignorance' (Peters 2005, p. 17). Effective leaders exploit these conflicts to achieve their ends.

Machiavelli took the need to win in a conflictual setting to the extreme, offering advice in The Prince (2008) about what a leader must do to win and maintain a dominant position. He encouraged the prince to be prepared to use whatever means necessary to preserve the prince's power. He believed leaders must set aside personal convictions and be guided only by those principles that help maintain their power and authority.

\subsection{Leaders and followers}

Until the 1970s, much of the leadership literature focused on what the leader could or should do to accomplish his ends. This paradigm shifted as leadership scholars began to acknowledge and explore the relationship between leaders and followers. In 1978, James MacGregor Burns defined what he called transactional leadership as "when one person takes the initiative ... with others for the purpose of an exchange of valued things' (Burns 1978, p. 19). In this conception, the leader, with a higher level of motivation, skill, and power than others, initiates the exchange. While this work expanded the scope of leadership studies to include the follower, Kellerman (2012) noted that '[i]n spite of the rise of the follower ... the leader is still the star' (p. 154) along with the implication 'that those that are not leaders are nothing much' (p. 156).

This relationship between leaders and followers mirrors that of the speaker and audience in communication studies. In the rhetorical model, the speaker uses language to influence people: the audience. Texts from two millennia ago detail how a speaker can persuade audiences, especially on civic issues. Aristotle's (1991) work On Rhetoric describes the process as 'an ability in each case to see the available means of persuasion' (Aristotle 1991, p. 36). This model calls for speakers to invent, arrange, and deliver messages based on an understanding of the particular audience, speaker, and subject matter. The parts of this rhetorical triangle function interdependently. When rhetoric works, the speaker and audience are in a contractual relationship whereby the eloquent speaker is rewarded with an agreeable audience. When leadership and authority work, the effective leader is rewarded with followers who 'fall in line.'

\section{HOW LEADERSHIP RESPONDS TO THE CIVIC CONTEXT}

Successfully exercising leadership means responding appropriately to the context in which it takes place. 'Leadership is highly contextual and what is appropriate or possible in one situation may be inappropriate or unattainable in another' (Brown 2014, p. 25). 
Unfortunately, most references to civic leadership assume that the civic context is much the same as any other leadership context or that political leadership is synonymous with civic leadership. From this perspective, portraying leaders as central actors untroubled by contextual differences is all that is needed.

Up until the last few decades, this dominant cultural view of leadership worked quite well in the civic arena. Small groups of powerful, public-spirited men - the city fathers - acted on behalf of the broader public. From their perspective, conflating the public good with private interest served the common good and preserved their influence. The great social movements of the 1960s and 1970s upset these informal structures and undermined the capacity of these men to cope with a diverse and fractious civic context (Chrislip and O'Malley 2013, pp. 21-24). The older, hierarchical relationship of a small group of leaders persuading followers of what needs to be done simply no longer works (Chrislip and Larson 1994, pp. 19-21; Easterling and Millesen 2012, p. 20; Peirce and Johnson 1997, p. 10).

\subsection{Process corrections in the civic arena}

The persistent failure of leadership to respond to civic challenges has not gone unnoticed. Over the past several decades scholars and practitioners - many outside of the field of leadership studies - have attempted to make leadership more responsive to the civic context. These experiments can be grouped into three areas: expanding conceptions of the leader-follower relationship; making the process of civic engagement more inclusive, constructive, and productive; and finding better ways of diagnosing the civic context and the complexity of its challenges.

\subsubsection{Expanding conceptions of the leader-follower relationship}

Over the past four decades the field of leadership studies has moved away from a narrow leader-centric focus to a more expansive view that includes other dimensions such as the leader's relationship with followers and the fulfillment of the needs of both. In his 1978 book, Leadership, Burns introduced a deeper conception of leadership that recognized a more profound link between leaders and followers and their mutual purposes. Transformational leadership, as he called it, encourages leaders and followers to engage in ways that 'raise one another to higher levels of motivation and morality' (Burns 1978, p. 20). In 1981, the great public servant, John Gardner, acknowledged the divisiveness of contemporary civic life, describing it as a 'war of the parts against the whole' (Gardner 1981, p. 19). Following Burns, he called for the development of 'networks of responsibility, leaders of disparate or conflicting interests who undertake to act together on behalf of the shared concerns of the community or nation' (ibid., p. 29, emphasis in original). Similarly, Joseph Rost, in his work on twenty-first century leadership, viewed leadership as a collective process joining leaders and followers in pursuit of real and intended change toward the mutual purposes of both (Rost 1993, p. 102). While this work expanded the scope of leadership studies, a central focus on the leader persists within much of the field and in the dominant cultural narrative (Uhl-Bien et al. 2014, p. 84). For example, within dyadic leadership - specifically leader member exchange (Graen and Uhl-Bien 1995, p. 232) and shared leadership research (Mehra et al. 2006, p. 233; Pearce and Sims 2002 , p. 172) - the leader remains the initiator and central agent of the process.

In their recent book, For the Common Good: Redefining Civic Leadership, Chrislip and O'Malley (2013) viewed civic leadership as 'a means of sharing responsibility for 
acting together in pursuit of the common good' rather than as a way of furthering individual desires (p. 1). In each of these examples, the focus of leadership shifts from fulfilling the narrow ends of the leader to the fulfillment of the broader purposes of both leaders and followers. These ideas helped guide and shape the emergence of more collaborative means for addressing civic challenges that had the potential to achieve a collective purpose.

\subsubsection{Making civic engagement more inclusive, constructive, and productive}

More people engaging in the public sphere has been an ideal of deliberative democracy throughout the twentieth century. This ideal contrasts starkly with a narrower view where the public expresses its preferences through the popular vote and delegates responsibility for enacting policies reflecting these views to its representatives (Ryan 2012, p. 960). This limited perspective places little or no expectation for leadership on citizens and residents of a place. The role of the public is simply to vote and get out of the way, allowing elected leaders to get on with the work.

In contrast, John Dewey's work on education and democracy operates from the premise that human society exists because of community. Communication allows people to work cooperatively to discover what they have in common (Dewey 1916, p. 4). When people help shape and evaluate public policy, a more legitimate democracy becomes possible. From 1936 to 1941, Dewey used the Federal Forum Project to organize and facilitate hundreds of public discussions. He and his partners believed 'that a revived and enhanced democratic practice, by fostering intelligent deliberation, could lead to solved problems and a brighter future' (Keith 2007, p. 293).

Dewey's pragmatic political philosophy argued that reasoned reflection was a superior way to deal with conflicting viewpoints in a diverse society. As Hicks and Langsdorf (1999) document, this procedural account of democracy 'views deliberation as a method for regulating disagreement and resolving differences of opinion through critical discussion' (p. 140).

Dewey's work on enhancing public engagement informed three experiments that shift the focus of leadership in the civic context from the individual and content to the group and process. First, public participation became common as a means of helping policy-makers gather input from those concerned. Second, public dialogue helped build a shared understanding of civic challenges allowing policy-makers to make more informed decisions. Finally, collaborative decision-making processes involving both authority figures and citizens helped build broader legitimacy for public decisions.

Protesters in the 1960s grabbed the headlines of the day through their aggressive questioning of those with ascribed influence or authority. No longer deferring to positional power, these protestors demanded justification of social policies and a voice in decisions that affected them. The resulting legislative measures forced government agencies to provide 'maximum feasible' public participation and require that official meetings be open to the public. For a short time these mechanisms worked before lobbyists and other interest groups figured out how to reclaim a dominant role. Soon enough, these ritualized, asymmetric processes began to frustrate and intimidate those who participated. Without dialogue or mutual learning, these perfunctory mechanisms further undermined public trust.

The use of dialogue in the civic arena attempts to correct for the dominating influence of powerful stakeholders. These inclusive and constructive engagements involving both authority figures and citizens build shared understanding across factional 
lines. By honing critical faculties for listening, inquiring, and advocating, these processes create the possibility for mutual learning.

Psychologists Kurt Lewin and Ron Lippitt prepared the way for this work in the 1940s. Working with community groups facing particular challenges, they used role-playing and small group discussions to help group members work through their differences and reach a shared understanding. Lewin called the three-part process they developed 'unfreezing,' 'learning,' and 'refreezing.' 'Unfreezing' allowed a person to suspend judgment and shed old beliefs, 'learning' provided new insights and approaches, and 'refreezing' solidified shared understanding (Kleiner 1996, p. 30).

When successful, the use of dialogue helps legislative bodies and authority figures make more informed decisions. In recent years, initiatives like the Kettering Foundation's National Issues Forum, America Speaks, and the World Café have provided new venues for this kind of public deliberation.

Collaborative decision-making goes a step further. These inclusive and constructive processes either have delegated authority or the collective influence to make decisions and hold organizations accountable for implementing them. They bring together those in authority positions along with others who care about or are affected by the presenting problems.

As long ago as the 1920s, Mary Parker Follett recognized the synergistic potential of joint action. She argued that working together in a deliberative way to bring out differences creates the possibility of a deeper, more integrated response that goes beyond the limitations of compromise and concession. Working with small deliberative groups in Boston, she had observed first-hand 'people learning how to evolve collective ideas' (Follett 1918 [1998], p. 19).

Since then, collaborative approaches to public decision-making have helped citizens and local governments in many places negotiate their way through competing interests and obligations (Brick et al. 2001, pp. 77-159; Chrislip and Larson 1994, pp. 40-51; Lasker and Weiss 2003, p. 15; Schuman 2006, pp. 322-447; Susskind et al. 1999, pp. 679-1086). These deliberative engagements complement the formal institutions of governance to cut across the divisiveness of interest group politics and legitimize public decisions. When these initiatives work they mitigate conflicts between competing interests, engage citizens deeply in addressing the problems that concern them, and build the capacity to negotiate future conflicts in ways that better reflect the common good (Chrislip and Larson 1994, pp. 100-104; Lasker and Weiss 2003, p. 21). Exercising leadership in these dynamic engagements requires a sustained focus on including diverse stakeholders while energizing and encouraging them to reach agreement through a mutual learning process rather than relying on authority and debate to convince others (Chrislip and Larson 1994, p. 53; Hicks and Larson 2012, p. 339; Lasker and Weiss 2003, pp. 30-31; Parks 2005, p. 46).

These three experiments - public participation, dialogue, and collaborative decisionmaking - have helped shift the focus of public and civic leadership from individuals solving content problems to managing process challenges to help groups make progress.

\subsubsection{Diagnosing the civic context}

As Kellerman noted in The End of Leadership, most writing on leadership assumes 'that context is of secondary or even tertiary consequence' (Kellerman 2012, p. 154). Making progress in the civic arena requires a deeper understanding of that particular context.

In the last half of the twentieth century, the diagnosis of civic challenges and the development of policies to address them became the domain of the 'best and the brightest.' These experts used their analytic skills to tease out optimal strategies or 
policies. This rational perspective with its attention on solutions generally ignored the context in which civic issues exist and the social dynamics that surround them. To compensate for these diagnostic shortcomings, practitioners experimented with three new approaches: distinguishing adaptive from technical challenges, systems thinking, and the use of scenarios to understand the current and future context.

In the 1990s, psychiatrist Ron Heifetz distinguished adaptive challenges from technical challenges. Adaptive issues have no clear 'right' answers. They cannot be resolved solely by expertise or routine behavior: 'To make progress, not only must invention and action change circumstances to align with values, but the values themselves may also have to change' (Heifetz 1994, p. 35). This distinction holds true in the civic arena, where the juxtaposition of complexity with the conflicting values of an increasingly diverse population overwhelms the capacity of experts to make progress. Answers, instead, must be invented or discovered through the mutual learning of stakeholders, hence the imperative to work across factions in collaborative ways.

If civic challenges are primarily adaptive, they are also systemic. They are embedded in complex, interrelated, self-correcting structures tending towards equilibrium. With equilibrium and complexity comes inertia; systems are hard to change. Without understanding these systemic aspects, responses tend to be symptomatic and short-lived rather than profound and sustainable.

In the early 1960s, Massachusetts Institute of Technology engineer and management professor Jay Forrester began to build computer models of complex industrial systems. The difficulty his students and the executives he worked with had in understanding the counter-intuitive logic of systems led him to believe that most managers' 'mental models were ill-suited for anticipating the future behavior of systems' (Forrester 1961, pp. 49-50).

In 1970, Forrester developed 'World,' a computerized model of the interaction of social and economic policies for the Club of Rome, a group of international business and political leaders. Prior to this work, most of the world's problems - for example, population, health, poverty, pollution, crime, education - had been seen in isolation. Forrester's model helped these policy-makers understand the systemic interrelationships between these different challenges and begin to think about how they might be addressed in a more coherent and holistic way. Rather than addressing symptoms, people could seek out leverage points that might move the system and experiment with interventions that could lead to deep change.

Peter Senge (1990, pp. 68-69) calls systems thinking 'a discipline for seeing wholes ... a sensibility for the subtle interconnectedness that gives living systems their unique character.' For him - and others like Ron Heifetz and Marty Linsky exercising leadership effectively means developing this capacity to see and understand the relationships within a social system in order to change it.

Just as we fail to understand the systemic aspects of civic challenges, public actions often take place with little recognition of the current and future contexts in which they occur. In the 1970s, a handful of iconoclastic planners at Royal Dutch Shell used scenarios to help the company make better decisions in a world of volatile oil prices. They had recognized that key variables affecting the company's future - for example, demographic change, growing social problems, globalization, changing technologies - are inherently unpredictable over long periods of time. Beyond a few years out, forecasting was inaccurate or impossible. If they couldn't develop a better way of grappling with this uncertainty, they would be of little help.

Similar to Forrester's observation that most managers' mental models failed to grasp the systemic nature of the challenges they faced, these planners noted that 
most of Shell's managers found it easier to assume that the future would be very much like the present rather than to consciously consider its unpredictability. By creating highly provocative yet plausible stories - scenarios - about how the future context might unfold, they hoped to goad others at the company into thinking differently and acting in more resilient ways.

Since then, the use of scenarios has expanded from the corporate world to governments, communities, regions, and countries. South Africans used scenarios to help plan for the transition from apartheid to democratic governance (Kahane 2012, pp. 4-13). Citizens and civic leaders used them to help determine the future of the non-profit sector in the Boston region and to plan for growth in Missoula, Montana (Chrislip 2002, pp. 206-216). Using scenarios helped these collaborative groups move from symptomatic reactions to systemic responses grounded in a deeper understanding of the context. These diagnostic tools are not simply planning techniques but, instead, ways of thinking - mental models - that must be cultivated by those exercising leadership in the civic arena.

\subsection{The gap still exists}

We've also learned through our experience that despite these corrections, civic leadership at its best doesn't fully respond to the civic context. As Project 17 illustrates, we still lack the leadership capacities and collective energy to reliably make progress on civic challenges. From our perspective, the dominant cultural narrative of leadership with its emphasis on the leader's authority and influence is too narrow, too goal-oriented, too manipulative to be of much help in the civic arena. We need a more subtle yet powerful and provocative conception of leadership.

James MacGregor Burns hints at what a more subtle view of leadership might look like in Transforming Leadership:

Instead of identifying individual actors simply as leaders or followers, we see the whole process as a system in which the function of leadership is palpable and central but the actors move in and out of leader and follower roles. At this crucial point we are no longer seeing individual leaders; rather we see leadership as the basic process of social change. (Burns 2003 , p. 185, emphases in original)

What would it take to make this vision of leadership come alive in the civic arena? For us, three aspects of leadership need attention: encouraging many more people to exercise leadership; keeping people engaged and energized in civic work; and measuring success in ways that match the complexity of the problems and the diversity of stakeholders.

\subsubsection{The one to the many}

A healthy civic culture invites, empowers, and includes anyone willing and able to exercise leadership in pursuit of the common good. 'To examine civic leadership is to invite ... a shift in attention to leadership as an action, not a position' (Couto 2014, p. 347), an activity that must be undertaken by many, not just a select few. Detaching leadership from authority and position and redefining it as an activity opens the opportunity to exercise leadership to anyone with the motivation to act (Chrislip and O'Malley 2013, p. 32; Heifetz and Sinder 1988, p. 194).

The activity of leadership in the civic arena requires some of these actors to detach themselves from self-interest, act without attachment to particular outcomes, and keep 
a steady focus on the common good. These ideas challenge the notion of the leader as the one who holds the vision, sets direction, and moves confidently forward. Instead, it places a high value on curiosity, doubt, listening, willingness to experiment, and the capacity to tolerate ambiguity. First order attention is on facilitating learning and building joint commitment rather than persuasion and influence. Leading in the civic context depends on engaging multiple stakeholders, diagnosing the situation, discovering common purpose, and experimenting with ways to intervene to make progress. With many more people exercising civic leadership in these different ways, progress becomes more likely (Chrislip and Larson 1994, p. 160; Chrislip and O'Malley 2013, pp. 159-160; Hicks and Larson 2012, pp. 335-337; Lasker and Weiss 2003, pp. 21-26).

\subsubsection{Keeping people in the work}

Project 17 highlights the challenges of energizing stakeholders to work together across factional lines. And it's not just about busy lives and conflicting priorities. The hard work of using traditional resistance strategies, the legal system, or public participation exhausts, alienates, and frustrates even those with the deepest commitment to public life. Even well-conceived and well-facilitated collaborative civic initiatives tend to deplete the energy of participants. What makes it so hard to stay in the game?

The initial excitement engendered by the creation of opportunities for citizens to participate dissipates quickly as the realities of conflicting views, difficult personalities, and potential losses hit home. With each step, the work becomes harder as it shifts from identifying challenges and opportunities to developing and agreeing on specific actions. As the understanding of the complexity of the challenges deepens so does the recognition that changing the status quo entails real sacrifices. Lacking the capacity to sustain the group's energy through these taxing times, most collaborations fail.

Communications scholar Darrin Hicks (2014, p. 3) notes: 'All of the best empirical research on collaboration comes to the same, seemingly straightforward conclusion: collaboration succeeds or fails to the extent that the affective energy of a group remains directed towards achieving a shared goal.' He goes on to describe examples of civic work that build affective energy - 'the dimension of experience in which a person feels eager to act and capable of action' (ibid., ch. 3, p. 7) - rather than depleting it. The leadership task then is to purposefully design and facilitate processes that mobilize this emotional energy.

These transformative experiences rely much more on below-the-neck work (affective) than above-the-neck work (logic and reason) to build energy and shared commitment. They reshape how we talk and engage in ways that make it possible for a participant to change one's mind and agree on common goals. Trust develops out of inclusion, transparency, shared information, and equal opportunity for participation. Constructed in the moment to respond to the context and the needs of the group, these processes allow participants to empathically entertain other points of view. The practice of 'cross-arguing' helps participants develop or change their convictions by taking on different perspectives while engaging with others allowing new, previously unimaginable, joint responses to emerge (Hicks 2002, pp. 240 and 254). Cultivating this affective appreciation of others' positions can motivate them to adopt a public-spirited perspective and a sense of collective responsibility (Hicks et al. 2008, p. 471). Mobilizing affective energy leads to deeper commitment and energizes rather than enervates people in civic life. 


\subsubsection{Measuring success}

Measuring success in these collaborative settings is a slippery task. For example, should an initiative like Project 17 use 'solid indicators' to measure progress towards a grand vision or use a comparative measure of progress - is the region better off now as the result of Project 17's actions than it would have been without them?

The economist and philosopher Amartya Sen (2009, p. 106) labels this a comparative assessment of justice. Sen contends that the fixation on transcendental ideals of justice gets in the way of making progress. Our evaluative efforts should be focused on how the world is becoming less unjust (ibid., p. 106). Under this comparative model, we would note progress when there was general agreement that a situation is better than it was before rather than whether an ideal state had been achieved or not (Judt 2010, p. 224; Kitcher 2014, p. 42; Sen 2009, pp. 15-17). From this perspective, progress in the civic arena would:

- depend on engaging others and working across factions rather than working in isolation;

- involve changing minds including one's own through learning and engaging with others rather than persuading and influencing others to adopt a point of view;

- celebrate small comparative gains rather than the achievement of a grand vision;

- require just enough trust, cohesion (joint acceptance), commitment, and agreement to move ahead rather than deep, 'best-friend' trust;

- need many people exercising leadership rather than the anointed few.

\section{ASK OF THE FIELD}

In her book, Hard Times, Barbara Kellerman (2015) describes conditions in 24 particular leadership contexts ranging from culture and class to economics and religion. She concludes that all of these arenas are becoming more complex and that the pressure on leaders to perform is unrelenting. At the same time, the power and authority of leaders is diminishing while the influence of followers is increasing. These trends are likely to continue well into the future (ibid., pp. 295-307).

Leadership, Kellerman says, will have to learn to cope with these conditions. Citing the example of political scientist Michael Genovese's recent list of central leadership competencies, she notes how removed from the context leadership models have become (ibid., p. 267). While noting the obvious - that leaders will have to become much better at diagnosing the context - she says little about what a more contextually responsive conception of leadership might look like. The civic arena mirrors the conditions Kellerman describes in other contexts. If, as scholars, educators, and practitioners, we have a common goal of advancing the field of leadership studies, a deeper understanding of what it takes to exercise leadership in the civic context can offer lessons applicable in these other contexts.

The central thesis of this paper asserts the inadequacy of the dominant cultural narrative of leadership for making progress on civic challenges. Now we need to advance an explicit and systematic focus on the civic context, a concerted effort to produce the leadership theories and pedagogical practices to work across and within factions without formal authority, in part, to counter the disappointment and cynicism that characterize many civic cultures. 
This paper is a call for interdisciplinary research to flesh out the daunting challenges of exercising leadership in the civic context and to experiment with ideas about leadership in collaborative settings. There is an opportunity to make progress within the field by continuing to test the corrective work acknowledged in this paper and by doing more research in the suggested new areas. Here are a few questions - some about theory and practice, some about pedagogy - that would help develop knowledge in this crucial arena:

\section{Theory and practice}

- What competencies are necessary to exercise leadership in the civic context?

- What does leadership with little or no authority look like?

- How should progress be measured in the civic arena recognizing the need for both expediency and the production of real and lasting results?

- How can leadership in the civic arena become more energizing than enervating?

- How can a deeper understanding of different contexts and what they demand of leadership be developed?

- What conceptions of leadership have the flexibility to adjust to different contexts?

- What can be done to help expand and reshape the dominant cultural narrative of leadership to reflect contemporary understandings of leadership within the field of leadership studies?

\section{Pedagogy}

- How can leadership education help people understand leadership as an activity rather than position or authority and motivate them to exercise leadership?

- How can leadership education help shift the focus from the individual as leader the dominant cultural narrative - to a systemic view of leadership as the basic process of social change?

Answering these questions will require us to challenge some of the norms of leadership studies and the methodologies that guide our research and practice. Couto, for example, suggests that methodologies for studying civic leadership should promote 'democratic ends and means by studying not only about or even for civic leadership, but participatory action methods with and by civic leadership' (Couto et al. 2009, p. 9). By enhancing theory, pedagogy, and practice within the field, the study of civic leadership can be a force for change that helps transform the civic culture and leads to the development of more capacious and flexible conceptions of leadership.

\section{REFERENCES}

Arendt, Hannah (1998), The Human Condition, 2nd edn, Chicago: University of Chicago Press.

Aristotle (1991), George A. Kennedy (trans.), On Rhetoric: A Theory of Civic Discourse, 1st edn, New York: Oxford University Press.

Baker, Susan D. (2007), 'The theoretical foundation of a contemporary construct,' Journal of Leadership \& Organizational Studies, 14(1), 50-60.

Brick, Philip, Don Snow, and Sarah Van de Wetering (eds) (2001), Across the Great Divide: Explorations in Collaborative Conservation and the American West, Washington, DC: Island Press.

Brown, Archie (2014), The Myth of the Strong Leader: Political Leadership in the Modern Age, New York: Basic Books. 
Burns, James MacGregor (1978), Leadership, New York: Harper and Row.

Burns, James MacGregor (2003), Transforming Leadership, New York: Atlantic Monthly.

Chrislip, David D. (2002), The Collaborative Leadership Fieldbook: A Guide for Citizens and Civic Leaders, San Francisco: Jossey-Bass.

Chrislip, David D. and Carl E. Larson (1994), Collaborative Leadership: How Citizens and Civic Leaders Can Make a Difference, San Francisco: Jossey-Bass.

Chrislip, David D. and Ed O'Malley (2013), For the Common Good: Redefining Civic Leadership, Wichita, KS: KLC Press.

Cicero, Marcus Tullius (46 BC [1899]), Charles D. Yonge (trans), The Orations of Marcus Tullius Cicero, London: The Colonial Press, reproduction.

Couto, Richard (2014), 'Civic leadership,' in R.A.W. Rhodes and Paul 't Hart (eds), The Oxford Handbook on Political Leadership, New York: Oxford University Press, pp. 347-361.

Couto, Richard, Sarah Hippensteel, and Marti Goertz (2009), 'Community change context,' in G.R. Hichman (ed.), Leading Change in Multiple Contexts, Thousand Oaks, CA: Sage, pp. 163-195.

Cronin, Thomas E. and Michael A. Genovese (2012), Leadership Matters: Unleashing the Power of Paradox, Boulder, CO: Paradigm Publishers.

Crowley, Sharon and Debra Hawhee (1999), Ancient Rhetorics for Contemporary Students, 2nd edn, Needham Heights, MA: Allyn and Bacon.

Dewey, John (1916), Democracy and Education: An Introduction to the Philosophy of Education, New York: Macmillan.

Dinh, Jessica E., Robert G. Lord, William L. Gardner, Jeremy D. Meuser, Robert C. Linden, and Jinyu $\mathrm{Hu}$ (2014), 'Leadership theory and research in the new millennium: current theoretical trends and changing perspectives,' The Leadership Quarterly, 25, 36-62.

Easterling, Doug and Judith L. Millesen (2012), 'Diversifying civic leadership: what it takes to move from "new faces" to adaptive problem solving,' National Civic Review, Summer, 20-26.

Economist, The (2013), 'The transience of power,' March 16, p. 70.

Economist, The (2014), 'The look of a leader,' September 27, p. 68.

Follett, Mary Parker (1918 [1998]), The New State: Group Organization the Solution of Popular Government, University Park, PA: Pennsylvania State University.

Forrester, Jay (1961), Industrial Dynamics, Cambridge, MA: MIT Press.

Gardner, John (1981), Leadership: A Sampler of the Wisdom of John Gardner, Minneapolis, MN: University of Minnesota.

Gentry, William A., Jennifer J. Deal, Marian N. Ruderman, Kristin L. Cullen, Anne M. Greenhalgh, and Christopher Maxwell (2014), 'Leadership is in the eyes of the beholder: how images of leadership that people have differ across the organization,' Report, Greensboro, NC: Center for Creative Leadership.

Graen, George B. and Mary Uhl-Bien (1995), 'Relationship-based approach to leadership: development of leader-member exchange (LMX) theory of leadership over 25 years: applying a multi-level multi-domain perspective,' The Leadership Quarterly, 6(2), 219-247.

Heifetz, Ron (1994), Leadership Without Easy Answers, Cambridge, MA: The Belknap Press.

Heifetz, Ron and Riley M. Sinder (1988), 'Political leadership: managing the public's problem solving,' in Robert B. Reich (ed.), The Power of Public Ideas, Cambridge MA: Ballinger, pp. 179-203.

Hicks, Darrin (2002), 'The promise(s) of deliberative democracy,' Rhetoric \& Public Affairs, 5(2), 223-260.

Hicks, Darrin (2014), The Transfer of Commitment, unpublished manuscript.

Hicks, Darrin and Lenore Langsdorf (1999), 'Regulating disagreement, constituting participants: a critique of proceduralist theories of democracy,' Argumentation, 13, 139-160.

Hicks, Darrin and Carl Larson (2012), 'Collaborating with others,' in J. Gaufin and B. Levy (eds), Mastering Public Health: Essential Skills for Effective Practice, Oxford: Oxford University Press, pp. 335-344.

Hicks, Darrin, Carl Larson, Christopher Nelson, David L. Olds, and Erik Johnston (2008), 'The influence of collaboration on program outcomes: the Colorado nurse family partnership,' Evaluation Review, 32, 453-477.

Judt, Tony (2010), Ill Fares the Land, New York: Penguin Press. 
142 Leadership and the Humanities, Vol. 4 No. 2

Kahane, Adam (2012), Transformative Scenario Planning, San Francisco: Berrett Koehler.

Kansas Health Institute (2009), Kansas County Health Rankings (2009), Topeka, KS: Kansas Health Institute.

Keith, William (2007), Democracy as Discussion: Civic Education and the American Forum Movement, Lanham, MD: Lexington Books.

Kellerman, Barbara (2012), The End of Leadership, New York: Harper Business.

Kellerman, Barbara (2015), Hard Times: Leadership in America, Stanford, CA: Stanford University Books.

Kitcher, Philip (2014), Life after Faith: The Case for Secular Humanism, New Haven, CT: Yale University Press.

Kleiner, Art (1996), The Age of Heretics: Heroes, Outlaws, and the Forerunners of Corporate Change, New York: Currency Doubleday.

Kosempel, Paul and Linda Olson (2013), 'Disrupting leadership definitions: a qualitative, semilongitudinal study of undergraduate conceptualizations of leadership,' Denver University, Power-Point Presentation.

Lasker, Roz D. and Elisa S. Weiss (2003), 'Broadening participation in community problem solving: a multidisciplinary model to support collaborative practice and research,' Journal of Urban Health: Bulletin of the New York Academy of Medicine, 80(1), 14-60.

Machiavelli, Niccolò (2008), Peter Bondanella (trans.), The Prince, New York: Oxford University Press.

McLean, Jim (2011), 'Call for unity resonates at Southeast Kansas economic summit,' Kansas Health Institute News Service, November 21, available at: http://www.khi.org/news/article/ southeast-kansas-economic-summit.

Mehra, Ajay, Brett Smith, Andrea Dixon, and Bruce Robertson (2006), 'Distributed leadership in teams: the network of leadership perceptions and team performance,' The Leadership Quarterly, 17, 232-245.

Parks, Sharon Daloz (2005), Leadership Can be Taught, Brighton, MA: Harvard Business Publishing.

Pearce, Craig L. and Henry P. Sims, Jr (2002), 'Vertical versus shared leadership as predictors of the effectiveness of change management teams: an examination of aversive, directive, transactional, transformational, and empowering leader behaviors,' Group Dynamics: Theory, Research and Practice, 6(2), 192-197.

Peirce, Neal and Curtis Johnson (1997), Boundary Crossers: Community Leadership Comes of Age, College Park, MD: The Burns Academy of Leadership Press.

Peters, John (2005), Courting the Abyss: Free Speech and the Liberal Tradition, Chicago: University of Chicago Press.

Project 17 Mission and Principles (2011), January, available at: http://www.twsproject17.org/ about/about-project-17/.

Putnam, Robert D. (2000), Bowling Alone: The Collapse and Revival of American Community, New York: Simon \& Schuster.

Rost, Joseph C. (1993), Leadership for the 21st Century, Westport, CT: Praeger.

Ryan, Alan (2012), On Politics, New York: Liveright.

Sanders, Charles G. (2014), 'Why the positional leadership perspective hinders the ability of organizations to deal with complex and dynamic situations,' International Journal of Leadership Studies, 8(2), 136-150.

Schuman, Sandy (ed.) (2006), Creating a Culture of Collaboration, San Francisco: Jossey-Bass. Sen, Amartya (2009), The Idea of Justice, Cambridge, MA: The Belknap Press.

Senge, Peter (1990), The Fifth Discipline: The Art and Practice of the Learning Organization, New York: Doubleday Currency.

Susskind, Larry, Sarah McKearnen, and Jennifer Thomas-Lamar (eds) (1999), The Consensus Building Handbook, Thousand Oaks, CA: Sage.

Uhl-Bien, Mary, Ronald E. Riggio, Kevin B. Lowe, and Melissa K. Carsten (2014), 'Followership theory: a review and research agenda,' The Leadership Quarterly, 25, 83-104. 